\title{
Agronomic characteristics of corn cultivars for silage production
}

\section{Características agronômicas de cultivares de milho para produção de silagem}

\author{
André Luis Alves Neves ${ }^{1 *}$; Rafael Dantas dos Santos²; Luiz Gustavo Ribeiro Pereira ${ }^{1}$; \\ José Nildo Tabosa ${ }^{3}$; Ítalo Reneu Rosas de Albuquerque ${ }^{4}$; Anselmo Luis Alves Neves ${ }^{5}$; \\ Getulio Figueiredo de Oliveira ${ }^{6}$; Rui da Silva Verneque ${ }^{1}$
}

\begin{abstract}
The objective of this study was to assess agronomic characteristics of five corn cultivars (BRS 1055, BRS 3035, BRS 2022, SÃO JOSÉ and BRS CAIMBÉ) recommended for silage production in Pernambuco State. At this productivity of green matter (PGM), productivity of dry matter (PDM), number of corn ears (NCE), plant height $(\mathrm{PH})$, ear insertion height $(\mathrm{EIH})$, plant population $(\mathrm{PP})$, percentage of broken plants (PBP) and proportions of ear, stem, and leaf in the GM and DM were determined. The experiment was set up in a randomized block design with five treatments (cultivars) and five replications. SÃO JOSÉ was prominent for $\mathrm{PH}, \mathrm{EIH}$, and $\mathrm{PBP}$, with mean values of $2.05 \mathrm{~m}, 1.15 \mathrm{~m}$, and $7.62 \%$, respectively. BRS 3035, BRS 2022, and BRS CAIMBÉ attained the highest PDM $\left(9.68,9.66\right.$, and $8.62 \mathrm{Mg} \mathrm{ha}^{-1}$, respectively). The evaluated cultivars had a good balance of leaf:stem:ear ratios and were in accordance with those exhibited by corn cultivars selected for silage production in different Brazilian regions. In general, the cultivars BRS 2022, BRS 3035, and BRS CAIMBÉ excelled in the most agronomic characteristics for silage production in the Borborema Plateau, a semiarid zone of Pernambuco State, when compared with the other cultivars.
\end{abstract}

Key words: Zea mays, semiarid, silage, forage, ruminant, nutrition

\section{Resumo}

O objetivo deste estudo foi avaliar as características agronômicas de cinco cultivares de milho (BRS 1055, BRS 3035, BRS 2022, SÃO JOSÉ and BRS CAIMBÉ) recomendados para produção de silagem no Agreste de Pernambuco. Para tanto foram determinadas as produtividades de matéria verde (PMV), de matéria seca (PMS), número de espigas (NE), altura de planta (AP), altura de inserção de espigas (AIE), população de plantas (PP), porcentagem de plantas quebradas (PQB) e as proporções de espiga (\%EMS), colmo (\%CMS) e folha (\%FMS) na matéria verde e na matéria seca. Foi utilizado o delineamento experimental em blocos ao acaso, com cinco tratamentos (cultivares) e cinco repetições. O cultivar SÃO JOSÉ destacou-se em relação à altura de planta, de inserção de espigas e porcentagem de plantas quebradas, apresentando média de 2,05m, 1,15m e 7,62\%, respectivamente. Os cultivares

\footnotetext{
${ }^{1}$ Analistas e Pesquisadores da Embrapa Gado de Leite, Juiz de Fora, MG, Brasil. E-mail: andre.neves@embrapa.br; luiz.gustavo@ embrapa.br; rui.verneque@embrapa.br

2 Pesquisador, Embrapa Semiárido, Petrolina, PE. E-mail: rafael.dantas@embrapa.br

3 Pesquisador, Instituto Agronômico de Pernambuco, IPA, Recife, PE, Brasil. E-mail: nildo.tabosa@ipa.br

${ }^{4}$ Discente do Curso de Doutorado em Ciência Animal nos Trópicos, Universidade Federal da Bahia, UFBA, Salvador, BA, Brasil. E-mail: italoreneu@hotmail.com

${ }^{5}$ Eng $^{\mathrm{o}}$ Agr ${ }^{\circ}$, Bom Jesus da Lapa, BA, Brasil. E-mail: anselmoluis.agro@gmail.com

${ }^{6}$ Discente do Curso de Graduação em Medicina Veterinária, Universidade Federal de Sergipe, UFS, Aracaju, SE, Brasil. E-mail: getuliotec@hotmail.com

* Author for correspondence
} 
BRS 3035, BRS 2022 e BRS CAIMBÉ obtiveram as maiores produções de matéria seca $(9,68,9,66$ e $8,62 \mathrm{Mg} \mathrm{ha}^{-1}$, respectivamente). Os cultivares avaliados apresentaram bom equilíbrio na relação folha: colmo: espiga e estão de acordo com os resultados apresentados para cultivares de milho consagrados para produção de silagem em distintas regiões brasileiras. Em geral, os cultivares BRS 2022, BRS 3035, and BRS CAIMBÉ se destacaram em relação aos demais nas características agronômicas para produção de silagem na Serra da Borborema, que é uma zona semiárida do estado de Pernambuco.

Palavras-chave: Zea mays, semiárido, silagem, forragem, ruminante, nutrição

\section{Introduction}

Corn is cultivated extensively throughout Brazil, which is the third largest producer worldwide, and there is a large potential for growth through exploiting different cultivars of this crop. This culture is valuable because of its multiple uses, both as human and animal food, and is considered one of the major agricultural products in the northeastern region of Brazil, where it covers an area of about 2.3 Mha (IBGE, 2012). However, corn yield is below the national means when it is grown for silage production in that region, most likely as a reflection of the particular local climate, technology used, and choice of inadequate cultivars. This can also be the result of a lack of knowledge about the agronomic performance of plants available and recommended for the semiarid region (SANTOS et al., 2010).

For these reasons, a great effort has been made to improve and release new corn cultivars based on the regional demands for cultivars that are adapted to the climatic variability of the Brazilian northeast and with better yield indices that can address the food shortage during the dry season (SILVA et al., 2003; PINHO et al., 2009; VITÓRIA et al., 2011). As corn can be easily ensiled owing to its high water soluble carbohydrate content and low buffering capacity, the selection of corn cultivars for silage production aims mainly to attain an economically viable product with a high grain/green matter (GM) ratio, which, when combined with suitable management of fertilization and harvest period, will produce larger yields of dry matter (DM) and grains, and result in a silage with higher nutritional value that is more digestible and has a lower fiber content (MELO et al., 1999).

From these considerations, the aim of this study was to evaluate agronomic characteristics of five corn cultivars, with the primary focus on the silage production.

\section{Material and Methods}

This investigation was conducted at the Experimental Station of the Agronomic Institute of Pernambuco State (IPA), in the municipality of São Bento do Una, Pernambuco State, Borborema Plateau $\left(08^{\circ} 31^{\prime} 22^{\prime \prime} \mathrm{S}\right.$ and $\left.36^{\circ} 26^{\prime} 40^{\prime \prime} \mathrm{W}\right)$. The area has an altitude of $640 \mathrm{~m}$; annual mean rainfall of $655 \mathrm{~mm}$; annual mean maximum and minimum temperatures of 32.6 and $11.7{ }^{\circ} \mathrm{C}$, respectively; a semi-arid megathermal climate; and soils predominantly of a sandy loam textural class, known as "psament."

Data relating to rainfall, temperature, evaporation, relative humidity, and wind velocity during the study are listed in Table 1 . 
Table 1. Meteorological data during the experimental period.

\begin{tabular}{|c|c|c|c|c|c|c|c|}
\hline \multirow{2}{*}{ Month/Year } & \multirow{2}{*}{ Days $^{1}$} & \multirow{2}{*}{ Rainfall (mm) ${ }^{2}$} & \multicolumn{3}{|c|}{ Temperature $\left({ }^{\circ} \mathrm{C}\right)$} & \multirow{2}{*}{ RH $(\%)^{3}$} & \multirow{2}{*}{ Wind $(\mathbf{k m ~ d a y})^{-1}$} \\
\hline & & & Max. & Min. & Mean & & \\
\hline May/2011 & 10 & 279.8 & 27.54 & 19.53 & 23.53 & 100 & 153.5 \\
\hline June/2011 & 09 & 43.1 & 27.13 & 17.35 & 22.24 & 99.69 & 163.2 \\
\hline July/2011 & 15 & 139.7 & 25.53 & 17.12 & 21.32 & 99.74 & 215.4 \\
\hline August/2011 & 12 & 19.7 & 26.88 & 16.01 & 21.44 & 99.79 & 222.3 \\
\hline
\end{tabular}

${ }^{1}$ Occurrence of rainfall in days; ${ }^{2}$ Rainfall in millimeters; ${ }^{3}$ Percentage relative humidity; ${ }^{4}$ Mean wind velocity at a height of $2 \mathrm{~m}$. Source: Meteorological Station of the Experimental Station São Bento do Una, Pernambuco State of the Agronomic Institute of Pernambuco State.

Source: Elaboration of the authors.

The experiment used a randomized block design with five treatments and five replications. Treatments consisted of five corn cultivars indicated for silage production in semiarid regions (Table 2). Plots with four rows, each $5.0 \mathrm{~m}$ in length and spaced $0.7 \mathrm{~m}$ apart, were used. Only the two central rows were considered useful areas, disregarding $0.5 \mathrm{~m}$ from each end. Each treatment comprised approximately 12 plants $\mathrm{m}^{-1}$, which was attained after thinning at 20 days after emergence.

Table 2. Agronomic description of corn cultivars.

\begin{tabular}{lcccc}
\hline \multicolumn{1}{c}{ Cultivars } & Type $^{\mathbf{1}}$ & Grain $^{\mathbf{2}}$ & Earliness $^{\mathbf{3}}$ & Grain $^{\text {color }}$ \\
\hline BRS 1055 & SH & SMT & ME & $\mathrm{R}$ \\
BRS 3035 & TH & SMT & VE & O \\
BRS2022 & DH & SMT & E & O \\
SÃO JOSÉ & V & SMT & E & Y \\
BRS CAIMBÉ & V & SMT & E & O/Y \\
\hline
\end{tabular}

${ }^{1}$ Type: $\mathrm{SH}$ - simple hybrid; TH - triple hybrid; DH - double hybrid; V - variety. ${ }^{2}$ Type of grain: SMT - semi-toothed. ${ }^{3}$ Earliness: $\mathrm{ME}$ - medium early, VE - very early, E - early. ${ }^{4} \mathrm{Grain}$ color: $\mathrm{R}$ - red; O - orange; Y - yellow; O/Y - orange and yellow.

Source: Elaboration of the authors.

Fertilization was performed according to chemical soil analysis, which showed the following characteristics: $\mathrm{pH}$ (water): $5.1 ; \mathrm{P}\left(\mathrm{mg} \mathrm{dm}^{-3}\right): 27$; $\mathrm{K}\left(\mathrm{cmol}_{\mathrm{c}} \mathrm{dm}^{-3}\right): 0.06 ; \mathrm{Al}\left(\mathrm{cmol}_{\mathrm{c}} \mathrm{dm}^{-3}\right): 0.20 ; \mathrm{H}+\mathrm{Al}$ $\left(\mathrm{cmol}_{\mathrm{c}} \mathrm{dm}^{-3}\right): 2.22 ; \mathrm{Ca}\left(\mathrm{cmol}_{\mathrm{c}} \mathrm{dm}^{-3}\right): 0.80 ; \mathrm{Mg}\left(\mathrm{cmol}_{\mathrm{c}}\right.$ $\left.\mathrm{dm}^{-3}\right)$ : 0.40; O.M. $\left(\mathrm{g} \mathrm{kg}^{-1}\right): 10.2$; value of saturation $(\mathrm{S})=\mathrm{Ca}+\mathrm{Mg}+\mathrm{Na}+\mathrm{K}\left(\left(\mathrm{cmol}_{\mathrm{c}} \mathrm{dm}^{-3}\right): 1.3\right.$; CEC (cation-exchange capacity) $=$ value of $\mathrm{S}+\mathrm{Al}+\mathrm{H}=$ $1.3+2.22=3.5\left(\mathrm{cmol}_{\mathrm{c}} \mathrm{dm}^{-3}\right)$; the value of CEC $(\%)$ $=($ value of S $/ \mathrm{CEC}) \times 100=36 \%$.

At sowing fertilization, we used $150 \mathrm{~kg} \mathrm{ha}^{-1}$ ammonium sulfate $+450 \mathrm{kgha}^{-1}$ triple superphosphate
$+100 \mathrm{~kg} \mathrm{ha}^{-1}$ potassium chloride. Two-side dressing fertilizations with a dose equivalent to $150 \mathrm{~kg} \mathrm{ha}^{-1}$ ammonium sulfate were applied on the $30^{\text {th }}$ day and on the $60^{\text {th }}$ day after plant emergence, periods that corresponds to the vegetative phases V3 and V6 respectively, as described by Cruz et al. (2008). Before fertilization, approximately $1 \mathrm{Mg} \mathrm{ha}^{-1}$ lime (magnesium) was applied to fix aluminum levels and raise calcium and magnesium concentrations.

Agronomic evaluations were performed when the plants exhibited grains in the middle of the cob at the dough/hard stage, which corresponds to the 
R5 stage of reproductive development of corn as reported by Cruz et al. (2008), by measuring the following: plant height $(\mathrm{PH}, \mathrm{m})$; ear insertion height (EIH, m); number of ears per plant ha ${ }^{-1}$; production of green matter (PGM, $\mathrm{Mg} \mathrm{ha}^{-1}$ ); production of dry matter (PDM, $\mathrm{Mg} \mathrm{ha}^{-1}$ ); percentage of ear, stem, and leaf in GM and DM, and number of broken plants (NBP). Cuttings were taken at $5 \mathrm{~cm}$ above ground level. Plants in the central rows were weighed after cutting and, based on the weight of plants in each row and their respective DM content, yields of GM and DM were calculated.

The NBP was recorded and values were transformed into percentages (NBP/total number of plants in the useful area of the plot). From each plot, a representative sample of five whole plants was weighed, packed into paper bags, and dried in a forced air oven at $65{ }^{\circ} \mathrm{C}$ for $72 \mathrm{~h}$. Samples were withdrawn from the oven and left at room temperature for $1 \mathrm{~h}$, after which they were weighed to determine the pre-dried matter. For DM, samples were ground in mills with 1-mm sieves, following the procedure of Silva and Queiroz (2002).

For determining the percentage of ear, stem, and leaf in DM, five plants/plot were randomly chosen. Later, the ears, stems, and leaves of each plant were dissected, weighed, and ground. The representativeness of each fraction was determined based on the resulting DM.

Variables were tested to check data normality, and later subjected to an analysis of variance, and means were compared using Tukey's test at the 5\% level. Pearson correlation coefficients were also calculated. All procedures were performed using $\mathrm{R}$ (R DEVELOPMENT CORE TEAM, 2011).

\section{Results and Discussion}

The number of ears was not significantly different among the cultivars used in the investigation (Table 3). There was an average of 1.23 ears per plant, which is higher than that found by Pinho et al. (2009) who observed a mean value of 0.97 ears/plant for different corn cultivars grown under different levels of fertilization. Yet ear insertion height was significantly different ( $\mathrm{P}$ $<0.05$ ) at the same plant population per ha among cultivars, with SÃO JOSÉ having the highest value $(1.15 \mathrm{~m})$. The mean EIH among all cultivars was $0.81 \mathrm{~m}$. In 2000, Farinelli et al. (2003) examined commercial cultivars in Jaboticabal (São Paulo State) in the off-season crop and verified a mean EIH of $0.75 \mathrm{~m}$, which is close to that recorded in cultivars studied in this experiment, while Beleze et al. (2003) showed values higher than the results from this study toward ear height $(1.22 \mathrm{~m})$ of early maturing corn hybrids.

Table 3. Number of ears per plant (NE), plant height $(\mathrm{PH})$, ear insertion height $(\mathrm{EIH})$ and percentage of broken plants (PBP) of the corn cultivars.

\begin{tabular}{lccccc}
\hline \multicolumn{1}{c}{ Cultivars } & $\mathbf{N E}^{\mathbf{1}}$ & ${\text { PH }(\mathbf{m})^{\mathbf{2}}}^{\mathbf{2}}$ & $\mathbf{E I H ~ ( m ) ~}^{\mathbf{3}}$ & Plants ha $^{\mathbf{1}}$ & PBP(\%) $^{\mathbf{4}}$ \\
\hline BRS 1055 & 1.2 & $2.00 \mathrm{~b}$ & $0.74 \mathrm{~b}$ & 61428 & $6.52 \mathrm{a}$ \\
BRS 3035 & 1.28 & $2.05 \mathrm{~b}$ & $0.74 \mathrm{~b}$ & 61714 & $1.34 \mathrm{~b}$ \\
BRS2022 & 1.2 & $1.97 \mathrm{~b}$ & $0.67 \mathrm{~b}$ & 62000 & $0.94 \mathrm{~b}$ \\
SÃO JOSÉ & 1.2 & $2.37 \mathrm{a}$ & $1.15 \mathrm{a}$ & 59714 & $7.62 \mathrm{a}$ \\
BRS CAIMBÉ & 1.28 & $1.86 \mathrm{~b}$ & $0.73 \mathrm{~b}$ & 61143 & $1.92 \mathrm{~b}$ \\
\hline Mean & 1.23 & 2.05 & 0.81 & 61200 & 3.66 \\
\hline CV (\%) & 16.15 & 7.33 & 15.47 & 6.24 & 45.81 \\
\hline
\end{tabular}

Mean values followed by different letters in the same column are significantly different $(\mathrm{P}<0.05)$ by Tukey's test.

Source: Elaboration of the authors. 
The PH of SÃO JOSÉ was $2.37 \mathrm{~m}$, which was superior to that of other cultivars $(\mathrm{P}<0.05)$ that had a mean PH of $2.05 \mathrm{~m}$. Santos et al. (2002) using 23 corn hybrids in Uberlândia (Minas Gerais State) observed a significant difference in $\mathrm{PH}$, with an mean of $1.84 \mathrm{~m}$ among cultivars, which was similar to that from the present study.

With regards to the PBP, which had a significant difference $(\mathrm{P}<0.05)$, SÃO JOSÉ and BRS 1055 had higher values at $7.62 \%$ and $6.52 \%$, respectively. These high PBPs for SÃO JOSÉ and BRS 1055 are most likely associated with higher PHs and EIHs (Tables 1 and 3).

The cultivars BRS 3035 and BRS 2022 were superior $(\mathrm{P}<0.05)$ to BRS 1055 and SÃO JOSÉ with respect to PGM and PDM and similar to yields of BRS CAIMBÉ (Table 4).

The means for PGM and PDM in this investigation (32.2 and $8.08 \mathrm{Mg} \mathrm{ha}^{-1}$, respectively) were lower than those found by Silva et al. (2003), Lupatini et al. (2004), and Paziani et al. (2009), who registered means of $37.43,45.04$, and 50.47 $\mathrm{Mg} \mathrm{ha} \mathrm{h}^{-1}$ for PGM and 12.24, 14.98, and 18.69 $\mathrm{Mg} \mathrm{ha} \mathrm{a}^{-1}$ for PDM, respectively, in the southeast region of Brazil. In dry areas, the PGM result was similar to that verified by Santos et al. (2010) at $33.8 \mathrm{Mg} \mathrm{ha}^{-1}$, whereas the PDM result was inferior to that found by Santos et al. (2010) (13.7 Mg ha${ }^{1}$ ), who worked with different corn cultivars for silage production in the northeast semiarid region, where the water demand for plants was met by irrigation. In spite of all the differences in yields across regions from Brazil, PGM and PDM are the first factors to be considered when gathering information about selection of a specific cultivar for silage production and on the planning and design of silos (FERRARI JUNIOR et al., 2005).

Table 4. Productions of green (PGM) and dry matter (PDM) of corn cultivars.

\begin{tabular}{lcc}
\hline \multicolumn{1}{c}{ Cultivars } & ${\text { PGM }\left(\mathbf{M g ~ h a}^{-1}\right)^{\mathbf{1}}}$ & PDM $\left(\mathbf{M g ~ h a}^{-1}\right)^{\mathbf{2}}$ \\
\hline BRS 1055 & $25.0 \mathrm{~b}$ & $6.12 \mathrm{~b}$ \\
BRS 3035 & $35.86 \mathrm{a}$ & $9.68 \mathrm{a}$ \\
BRS2022 & $40.28 \mathrm{a}$ & $9.66 \mathrm{a}$ \\
SÃO JOSÉ & $25.6 \mathrm{~b}$ & $6.12 \mathrm{~b}$ \\
BRS CAIMBÉ & $34.3 \mathrm{ab}$ & $8.62 \mathrm{ab}$ \\
\hline Mean & 32.2 & 8.04 \\
\hline CV (\%) & 15.51 & 20.43 \\
\hline
\end{tabular}

Mean values followed by different letters in the same column are significantly different $(\mathrm{P}<0.05)$ using Tukey's test.

Source: Elaboration of the authors.

As for the percentage of ear, stem, and leaf of each corn cultivar based on GM and DM, only the percentage of ears in GM was significantly different $(\mathrm{P}<0.05)$, with BRS 1055 and BRS CAIMBÉ exhibiting the highest percentages $(43 \%$ and $43.6 \%$, respectively), but similar to that of BRS 3035 and BRS 2022. This value was lower in SÃO JOSÉ, at $35 \%$ of ear in GM, but equal to BRS 3035 and BRS 2022 (Table 5).

Table 5. Percentage participation of ear, stem, and leaf on green matter (GM) and dry matter (DM) basis in different corn cultivars

\begin{tabular}{lcccccc}
\hline \multirow{2}{*}{ Cultivars } & \multicolumn{2}{c}{ Ear } & \multicolumn{2}{c}{ Stem } & \multicolumn{2}{c}{ Leaf } \\
\cline { 2 - 7 } & \%GM & \%DM & \%GM & \%DM & \%GM & \%DM \\
\hline BRS 1055 & $43.0 \mathrm{a}$ & 42.2 & 36.6 & 37.2 & 20.4 & 20.6 \\
BRS 3035 & $41.6 \mathrm{ab}$ & 38.4 & 39.8 & 39.4 & 18.6 & 22.2 \\
BRS 2022 & $41.8 \mathrm{ab}$ & 36.8 & 40.8 & 43.4 & 17.4 & 19.8 \\
SÃO JOSÉ & $35.0 \mathrm{~b}$ & 34.0 & 44.4 & 42.4 & 20.6 & 23.6 \\
BRS CAIMBÉ & $43.6 \mathrm{a}$ & 39.2 & 38.8 & 40.8 & 17.6 & 20.0 \\
\hline Mean & 41.0 & 38.12 & 40.08 & 40.64 & 18.92 & 21.24 \\
\hline CV (\%) & 9.66 & 14.43 & 10.46 & 13.94 & 9.20 & 13.47 \\
\hline
\end{tabular}

Mean values followed by different letters in the same column are significantly different $(\mathrm{P}<0.05)$ by Tukey's test.

Source: Elaboration of the authors. 
On the other hand, the percentages of ear in GM and stem and leaf in GM and DM were not different among cultivars, affirming that these materials possessed similar phenological characteristics. Mean values of the proportion of stem and leaf in DM were $40.64 \%$ and $21.24 \%$, respectively. The percentage of leaf in DM was similar to that found by Santos et al. (2010) with corn cultivars for silage in the drier areas of Pernambuco State, at a mean value of $19.0 \%$. However, the percentage of stem observed in this study (28.4\%) was greater than that found by these authors for this variable.

In general, lower proportion of stems in plant tissue towards leaves and ears can contribute to increasing the whole plant's dry matter digestibility as the increase in stem proportion and cell wall content could result in a higher concentration of ADF, which is inversely correlated to the nutritive value of corn silages. For this reason, analysis of the proportionality relationship among ear, stem, and leaf is very important because it indicates the potential of these cultivars to provide soluble carbohydrates in adequate amounts for optimal fermentation and, consequently, the production of high-quality silages with high productivity (SANTOS et al., 2010).

With respect to the different correlations, $\mathrm{PH}$ was not positively correlated with PBP (Table 6), and this is an extremely desirable characteristic for achieving efficient productions of silage because plants that exhibit lower lodging rates as a reflection of a reduced PBP percentage possess lower losses of yield in the field during the mechanical process of harvest. It is important to mention that plant height and EIH showed no positive correlation with PGM and PDM (Table 6), being different from those obtained by Paziani et al. (2009), who detected significant correlations for these variables in populations of corn for silage production. The differences in correlations between the current work and those of Paziani et al. (2009) could be arisen from the lower earliness of flowering of the cultivars grown by those authors that could cause a different behavior towards earlier cycles and consequently greater PGM, PDM, and percentage of grains in the ear, variables that are highly correlated with the plant size.

Table 6. Correlation coefficients of studied variables in corn cultivars.

\begin{tabular}{|c|c|c|c|c|c|c|c|c|c|c|c|c|}
\hline Variable & PP & NE & EIH & PBP & PGM & PDM & $\begin{array}{c}\% \\
\text { EGM }\end{array}$ & $\begin{array}{c}\% \\
\text { EDM }\end{array}$ & $\begin{array}{c}\% \\
\text { SGM }\end{array}$ & $\begin{array}{c}\% \\
\text { SDM }\end{array}$ & $\begin{array}{c}\% \\
\text { LGM }\end{array}$ & $\begin{array}{c}\% \\
\text { LDM }\end{array}$ \\
\hline HP & -0.37 & -0.24 & $0.55^{* *}$ & 0.34 & -0.22 & -0.20 & -0.34 & -0.16 & 0.23 & 0.02 & 0.27 & 0.27 \\
\hline PP & - & 0.19 & -0.02 & -0.10 & -0.05 & -0.05 & 0.09 & -0.12 & -0.09 & 0.05 & -0.02 & 0.15 \\
\hline $\mathrm{NE}$ & - & - & -0.01 & 0.15 & -0.03 & -0.10 & 0.11 & 0.00 & 0.01 & -0.05 & -0.25 & 0.09 \\
\hline EIH & - & - & - & $0.51^{* *}$ & -0.20 & -0.21 & $-0.52^{* *}$ & -0.25 & $0.47^{*}$ & 0.07 & 0.20 & 0.36 \\
\hline PBP & - & - & - & - & $-0.62^{* *}$ & $-0.64^{* *}$ & -0.39 & -0.20 & 0.20 & 0.07 & $0.40^{*}$ & 0.26 \\
\hline PGM & - & - & - & - & - & $0.93^{* *}$ & $0.45^{* *}$ & $0.33^{* *}$ & -0.11 & -0.20 & $-0.69^{* *}$ & $-0.28^{* *}$ \\
\hline PDM & - & - & - & - & - & - & $0.38^{* *}$ & $0.28^{* *}$ & -0.08 & -0.21 & $-0.60^{* *}$ & -0.18 \\
\hline$\%$ EGM & - & - & - & - & - & - & - & $0.82^{* *}$ & $-0.86^{* *}$ & $-0.65^{* *}$ & $-0.47^{*}$ & $-0.43^{*}$ \\
\hline$\%$ EDM & - & - & - & - & - & - & - & - & $-0.76^{* *}$ & $-0.87^{* *}$ & -0.28 & -0.39 \\
\hline$\% \mathrm{SGM}$ & - & - & - & - & - & - & - & - & - & $0.73^{* *}$ & -0.05 & 0.17 \\
\hline$\% \mathrm{SDM}$ & - & - & - & - & - & - & - & - & - & - & 0.01 & -0.11 \\
\hline$\%$ LGM & - & - & - & - & - & - & - & - & - & - & - & $0.53^{* *}$ \\
\hline
\end{tabular}

${ }^{*} \mathrm{P}<0.05$ (significant); $* * \mathrm{P}<0.01$ (highly significant); ${ }^{1} \mathrm{PH}-$ plant height; $\mathrm{NE}$ - number of ears; EIH - ear insertion height; PP - plant populations; PBP - broken plants (\%); PGM - production of green matter; PDM - production of dry matter; \%EGM proportion of ear in the green matter; \%EDM - proportion of ear in the dry matter; \% $\% \mathrm{SG}$ - proportion of stem in the green matter; $\% \mathrm{SDM}$ - proportion of stem in the dry matter; \%LGM - proportion of leaf in the green matter; \%LDM - proportion of leaf in the dry matter.

Source: Elaboration of the authors. 
The percentage of ears was negatively correlated $(p<0.05)$ with the stem and leaves, which shows the effect of dilution of this component with an increasing proportion of the other plant components. However, percentage of ears was positively correlated $(\mathrm{P}<$ $0.05)$ with PGM and PDM $(0.45,0.33,0.38$, and 0.28, respectively). According to Almeida Filho et al. (1999) and Flaresso, Gross and Almeida (2000), the determination of the ear fraction is fundamental as it is positively correlated with the increase in the content of DM, and production of grains. However, the proportion of ear in DM should not be considered the only characteristic in selecting corn cultivars for silage production because both the fiber quality and $\mathrm{PH}$ influence PDM and silage quality.

Other correlation coefficients for the examined variables are consistent with those presented for corn cultivars devoted to silage production in different Brazilian regions, indicating the possibility of using these materials for silage production in the northeast semiarid region.

\section{Acknowledgements}

The authors thank CNPq/CTAgro Grant Number 555708/2009-8 and Banco do Nordeste do Brasil Grant Number 7539 for the financial support.

\section{Conclusions}

In general, the cultivars BRS 2022, BRS 3035, and BRS CAIMBÉ excelled in the most agronomic characteristics for silage production in the Borborema Plateau, a semi-arid zone of Pernambuco State, when compared with the other cultivars.

\section{References}

ALMEIDA FILHO, S. L.; FONSECA, D. M.; GARCIA, R.; OBEID, A. J.; OLIVEIRA, J. S. Características agronômicas de cultivares de milho (Zea mays L.) e qualidade dos componentes da silagem. Revista
Brasileira de Zootecnia, Viçosa, MG, v. 28, n. 1, p. 7-13, 1999.

BELEZE, J. R. F.; ZEOULA, L. M.; CECATO, U.; DIAN, P. H. M.; MARTINS, E. N.; FALCÃO, A. J. S. Avaliação de cinco híbridos de milho (Zea mays, L.) em diferentes estádios de maturação. 1. Produtividade, características morfológicas e correlações. Revista Brasileira de Zootecnia, Viçosa, MG, v. 32, n. 3, p. 529537, 2003.

CRUZ, J. C.; KARAM, D.; MONTEIRO, M. A. R.; MAGAlHAES, P. C. (Ed.). A cultura do milho. Sete Lagoas: Embrapa Milho e Sorgo, 2008. 517 p.

FARINELLI, R.; PENARIOL, F. G.; BORDIN, L.; COICEV, L.; FORNASIERI FILHO, D. Desempenho agronômico de cultivares de milho nos períodos de safra e safrinha. Revista Bragantia, Campinas, v. 62, n. 2, p. 235-241, 2003.

FERRARI JUNIOR, E.; POSSENTI, R. A.; LIMA, M. L. P.; NOGUEIRA, J. R.; ANDRADE, J. B. Características, composição química e qualidade de silagens de oito cultivares de milho. Boletim de Indústria Animal, Nova Odessa, v. 62, n. 1, p. 19-27, 2005.

FLARESSO, J. A.; GROSS, C. D.; ALMEIDA, E. D. Cultivares de milho (Zea mays L.) e Sorgo (Sorghum bicolor (L.) Moench.) para ensilagem no alto Vale do Itajaí, Santa Catarina. Revista Brasileira de Zootecnia, Viçosa, MG, v. 29, n. 6, p. 1608-1615, 2000.

INSTITUTO BRASILEIRO DE GEOGRAFIA E ESTATÍSTICA - IBGE. Pesquisa Municipal Agrícola 2012. Disponível em: <http://www.ibge.gov.br/home/ estatistica/pesquisas/pesquisa_resultados.php?id_ pesquisa $=44>$. Acesso em: 24 mar. 2015.

LUPATINI, G. C.; MACCARI, M.; ZANETTE, S.; PIACENTINI, E.; NEUMANN, M. Avaliação do desempenho agronômico de híbridos de milho (Zea mays, L.) para produção de silagem. Revista Brasileira de Milho e Sorgo, Sete Lagoas, v. 3, n. 2, p. 193-203, 2004.

MELO, W. M. C.; PINHO, R. G. V.; CARVALHO, M. L. M.; PINHO, E. V. R. Avaliação de cultivares de milho para produção de silagem na região de Lavras - MG. Ciência e Agrotecnologia, Lavras, v. 23, n. 1, p. 31-39, 1999.

PAZIANI, S. F.; DUARTE, A. P.; NUSSIO, L. G.; GALLO, P. B.; BITTAR, C. M. M.; ZOPOLLATTO, M.; RECO, P. C. Características agronômicas e bromatológicas de híbridos de milho para produção de silagem. Revista Brasileira de Zootecnia, Viçosa, MG, v. 38, n. 3, p. 411-417, 2009. 
PINHO, R. G. V.; RIVERA, A. A. C.; BRITO, A. H.; LIMA, T. G. Avaliação agronômica do cultivo de milho em diferentes níveis de investimento. Ciência e Agrotecnologia, Lavras, v. 33, n. 1, p. 39-46, 2009.

R DEVELOPMENT CORE TEAM. R: A language and environment for statistical computing. Vienna: $\mathrm{R}$ Foundation for Statistical Computing, 2011.

SANTOS, P. G.; JULIATTI, P. Z.; BUIATTI, A. L.; HAMAWAKI, O. T. Avaliação do desmpenho agronômico de híbridos de milho em Uberlândia, MG. Pesquisa Agropecuária Brasileira, Brasília, v. 37, n. 5, p. 597-602, 2002.

SANTOS, R. D.; PEREIRA, L. G. R.; NEVES, A. L. A.; AZEVÊDO, J. A. G.; MORAES, S. A.; COSTA, C. T. F. Características agronômicas de variedades de milho para produção de silagem. Acta Scientiarum. Animal Sciences, Maringá, v. 32, n. 4, p. 367-373, 2010.
SILVA, D. J.; QUEIROZ, A. C. Análise de alimentos: métodos químicos e biológicos. Viçosa: UFV, 2002. 235 p.

SILVA, P. C.; OSUNA, J. T. A.; MORO, J. R.; PAIVA, L. M.; QUEIROZ, S. R. O. D.; MARTINS, M. R. Avaliação de híbridos interpopulacionais de milho quanto a características químicas e agronômicas para silagem. Revista Brasileira de Milho e Sorgo, Sete Lagoas, v. 2, n. 3, p. 111-120, 2003.

VITÓRIA, E. L.; LONGUI, F. C.; FERNANDES, H. C.; GUIMARÃES FILHO, C. C. Influencia do tipo de preparo do solo e velocidade de semeadura em características agronômicas da cultura do milho. Revista Agrotecnologia, Anápolis, v. 2, n. 2, p. 44-52, 2011. 